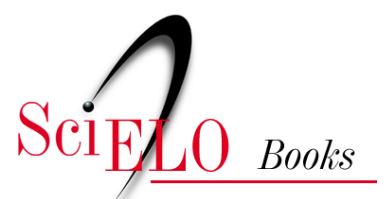

\title{
Segundo Episódio \\ crianças partidas, crianças perfeitas ou as lagostas azuis
}

\author{
Ana Cristina Bohrer Gilbert
}

\section{SciELO Books / SciELO Livros / SciELO Libros}

GILBERT, A.C.B. Segundo Episódio: crianças partidas, crianças perfeitas ou as lagostas azuis. In: Vértice do impensável: um estudo de narrativas em síndrome de Down [online]. Rio de Janeiro: Editora FIOCRUZ, 2012, pp. 87-113. Criança, mulher e saúde collection. ISBN: 978-85-7541-572-6. https://doi.org/10.7476/9788575415726.0006.

All the contents of this work, except where otherwise noted, is licensed under a Creative Commons Attribution 4.0 International license.

Todo o conteúdo deste trabalho, exceto quando houver ressalva, é publicado sob a licença Creative Commons Atribição $\underline{4.0}$. 


\section{SEguindo Episódio: \\ CRIANCAS PARTIDAS, CRIANCCAS \\ PERFEITAS OU AS LAGOSTAS AZUIS}

Toda prática científica é, em certa medida, uma prática narrativa relacionada a formas de interpretação e visões de mundo que se modificam historicamente e que dão sentido aos novos desenvolvimentos tecnocientíficos.

Os avanços científicos são acompanhados por imagens e imaginação; um construto científico está muitas vezes associado ou mesmo baseado numa imagem reconhecida como desejável ou familiar. Diferentes grupos, especializados ou não, utilizam ambas, imagens e imaginação, na construção e busca por validação dos seus debates em torno do campo da ciência em geral e da genética, em particular. Novas tecnologias requerem novas imagens e novos elementos no processo imaginativo. Entretanto, tais reformulações não acontecem facilmente, muitas vezes prevalecendo uma releitura de antigas imagens (Van Dijck, 1998). O uso de linguagem figurada abre novas perspectivas, por sua flexibilidade e imprecisão, para clarificar fenômenos, cuja novidade se faz sentir na ausência de palavras para descrevê-los.

O conhecimento genético que é disseminado está entremeado por fantasias de um futuro promissor, com novas esperanças e expectativas de controle, mas que ao mesmo tempo infunde medo diante do imprevisível e desconhecido, e é revestido por um alto teor de apelo dramático, por meio de imagens ou histórias narradas. 
Este segundo episódio discute livros e blogs escritos e produzidos por pais de pessoas com síndrome de Down (SD). Apesar de serem relatos de histórias 'reais', isto é, não ficcionais, contêm elementos narrativos que reproduzem as mesmas imagens e componentes imaginativos de produções tanto científicas quanto ficcionais. Acaso e determinismo, capacidade e configuração genética, identidade biológica e social são alguns dos aspectos presentes nas narrativas analisadas.

A entrada de voz dá respostas ao tema principal e à primeira voz, reafirmando-as; contudo, deixa entrever dissonâncias e ambivalências, harmonizadas por meio da variação contrapontística.

\section{Construção Pública do SelF}

O contexto da genética, analisado por José Van Dijck (1998) por meio da utilização da metáfora do teatro, envolve uma dose de dramatização, de apelo emocional, que é necessária à disseminação dos seus conceitos e debates. Personagens (cientistas, geneticistas), enredos (de aventura, de detetives ou de competição) e metáforas (genoma como mapa, gene como código, só para citar as mais comuns) são os principais instrumentos narrativos na atuação do teatro da genética, os quais se articulam às referências que o público em geral faz a esse campo, bem como à dinâmica de produção de sentidos.

Em vez de um modelo linear de difusão do conhecimento científico, Van Dijck, com essa metáfora, reforça a circularidade como predominante, aspecto já enfatizado por outros autores como Ludwik Fleck (1981), que enfoca o entrelaçamento existente entre o conhecimento gerado no círculo científico ou esotérico e o que circula na comunidade leiga ou círculo exotérico, e Carlo Ginzburg (2002), que usa a expressão 'circularidade de ideias' para desfazer a noção de que as informações originadas no círculo especializado são distorcidas ou sofrem deterioração ao serem assimiladas pelo círculo leigo.

Os livros e blogs analisados, apesar de pertencerem a contextos culturais diferentes, ainda que ocidentais, apresentam um conteúdo que não 
difere substancialmente, não apenas porque a SD independe de etnia, cultura ou nível socioeconômico, mas também porque na era genômica as identidades individuais transcendem as fronteiras nacionais para se conformarem como identidades essencialmente biológicas, moldadas por características vitais específicas.

Nas narrativas, o individual se entrelaça ao social; são relatos particulares, experienciais, mas que formam parte de um mesmo gênero que as engloba, o gênero confessional, e que têm como contexto mais abrangente a presença de uma condição genética específica, a SD. Tais práticas sociais servem ao propósito de construção, abertura e exposição de um novo self, em que a experiência vivida é o mais importante.

Com a frase 'meu filho tem SD' começa a construção de uma identidade pautada pelo somático, que se a princípio é exposta nos sinais aparentes na superficialidade do corpo, adiante é materializada na abstração do construto do cromossomo 21 extra, ao qual os pais têm acesso via cariótipo representado num papel impresso, e que (re)interpreta a pessoa em sua própria corporalidade.

Narrar é uma característica comum aos seres humanos. Narrar experiências por meio de livros ou blogs contribui para tornar o estranho familiar, a fim de dar significado ao vivido e sentido. Além do suporte emocional proposto, as narrativas têm a intenção de apresentar ou facilitar caminhos para, em termos práticos, tornar menos traumática a convivência com a presença da SD no filho, estimulando a busca por informação e por intervenções cada vez mais precoces.

Na grande maioria dos casos, a exposição é feita por pais ou parentes de pessoas com SD, mas também existem narrativas feitas por essas próprias pessoas. Os elementos principais de tais discussões são os desafios e conflitos enfrentados quando no momento do diagnóstico, seja ele feito ao nascer, seja ainda durante a gestação, e o processo de criação de um filho com SD, com dúvidas, questionamentos e necessidades de decisões relativas a um futuro que se apresenta incerto.

Transmitir experiências a outras pessoas com vivências semelhantes ou não cria uma forma de identidade compartilhada que une uma 
audiência, anônima em sua maioria, e que se traduz numa espécie de parentesco que acolhe, apoia, estimula e compreende o que antes era impensável. Concomitantemente, essas experiências se espraiam, tecendo redes que atuam como verdades plurais, gerando controvérsia, dúvida e questionamento em relação ao discurso biomédico, tornado monólogo.

A construção de narrativas por pacientes e famílias como forma de lidar com a presença de uma condição crônica específica que acarreta uma quebra nas suas vidas, com consequente alteração de identidade, foi alvo de estudo de vários autores desde a segunda metade do século XX. Um desses autores, Anne Hunsaker Hawkins (1999), utiliza o termo patografia para definir um gênero de narrativas no qual uma experiência profundamente traumática e destrutiva relacionada ao adoecimento é relatada, bem como as alternativas encontradas para com ela conviver e de algum modo transformá-la em uma experiência restauradora.

As narrativas em SD analisadas se aproximam em alguns aspectos das patografias estudadas por Hawkins (1999), especialmente no seu caráter de suporte diante de uma situação de adoecimento que se apresenta como desconhecida e ameaçadora da integridade de uma pessoa, e na identificação de elementos metafóricos comuns utilizados para descrever a experiência e lhe dar sentido.

Contudo, outros aspectos as diferenciam: em primeiro lugar, por ser a SD uma condição que já está manifesta ao nascer, não existe quebra no processo de vida da criança, isto é, um antes e um depois da SD, por mais que intercorrências graves, como uma cirurgia, por exemplo, funcionem como marcos importantes. A quebra se dá na vida das pessoas à sua volta, especialmente dos pais. Em segundo lugar, o fato de que, apesar de profundamente traumática a princípio, a experiência de ter um filho com SD é relatada como definitivamente compensadora para as vidas das pessoas envolvidas.

Os eventos escolhidos para serem registrados, mais do que vivências individuais, são expressões de um determinado grupo, uma vez que a seleção do que vai ser lembrado (e como) e daquilo que não vale a pena ser registrado como evento marcante é função também de uma importância incorporada 
socialmente. Os livros e blogs, produtos desses registros, tornam-se atos culturais coletivos e, muitas vezes, são resultado de uma indústria da memória que se alimenta dessas narrativas, sejam elas livros, sejam filmes, fotografias ou outros objetos de memória.

Recordar não é trazer um passado estocado e pronto, mas reatualizar experiências quando evocadas. Lembrar para registrar modifica a experiência vivida por seu aspecto seletivo, mas também pelas novas cores e interpretações dadas a emoções e reflexões após sua vivência. Registrar, portanto, é também criar. Da mesma forma, ler é uma forma de reescrever. Nas palavras poéticas de Gabriel García Marquez (2003), "la vida no es la que uno vivió, sino la que uno recuerda y cómo recuerda para contarla". ${ }^{1}$

No processo de memória e recontagem das histórias em SD, a realização dos testes pré-natais - em especial aqueles que fornecem imagens, como as ultrassonografias (USG) feitas nos diferentes trimestres, com a medida da translucência nucal (TN) para avaliação do risco de anomalias cromossômicas no primeiro trimestre; a morfológica para avaliação do crescimento, desenvolvimento e das estruturas fetais no segundo; e as USGs 3D e 4D $-^{2}$ forma parte dos ritos compartilhados que são narrados e criam memórias anteriores ao nascimento que começam a compor o álbum do bebê e a embalar as expectativas e fantasias com relação a ele.

Quando essas imagens revelam algo diferente, que não está de acordo com uma norma reconhecida socialmente como desejável, outras emoções são acrescidas a esses eventos. Novos testes, como a biópsia de vilo corial, a amniocentese e a cordocentese, por exemplo, são realizados na busca por transformar possibilidades em respostas. Tais memórias mediadas a um só tempo moldam e são moldadas pela mídia utilizada no seu registro - no caso, os livros e blogs.

\section{ERA UMA VEZ...}

As narrativas em SD na forma de livro se multiplicaram a partir dos anos 80, numa tendência crescente de lançar luz sobre o que era a SD e, principalmente, trazer da sombra as pessoas que com ela nasciam. $\mathrm{O}$ declínio do uso do termo 'mongolismo', cujo caráter pejorativo foi sendo 
cada vez mais criticado, e a sua substituição pelo termo síndrome de Down ou trissomia do 21 impulsionaram a sociedade para uma discussão mais abrangente sobre o assunto.

Contudo, não obstante as diferenças culturais, os semas presentes nas narrativas são similares, bem como a mitologia que as embasa, aqui entendida, de forma ampla, como um conjunto de relatos simbólicos que narram e explicam a origem de determinados fenômenos (Henderson, 1996).

A análise dos relatos destaca a existência de uma estrutura narrativa comum, com personagens, ações específicas, partes constituintes, desenlaces. Alguns relatos seguem o sintagma narrativo básico, o modelo temporal linear equilíbrio-ruptura-equilíbrio. Outras apresentam um desdobramento dessa estrutura básica, comparável ao esquema em cinco partes desenvolvido por Tzvetan Todorov (1969) em sua poética estruturalista sobre o aspecto sintático do texto. Esse esquema é composto de três momentos estáticos (1, 3 e 5) e dois dinâmicos (2 e 4), e as relações são predominantemente sequenciais ou temporais: 1) situação inicial (que descreve a vida antes da chegada da criança até os momentos iniciais da gravidez); 2) perturbação da situação inicial (a suspeita de que algo não é como o esperado); 3) desequilíbrio ou crise (o diagnóstico); 4) intervenção na crise (a busca por informação ou grupos de suporte, a partir da qual a situação começa a mudar); 5) novo equilíbrio (semelhante ou não à situação inicial).

Nos relatos, a sequência da narração pode ou não ser cronológica e na maioria das vezes não o é -, mas os momentos são identificáveis, implícita ou explicitamente; o ponto de corte é o nascimento ou o diagnóstico via USG.

Observa-se a presença de relações espaciais não apenas nas imagens, mas evocadas também nos textos escritos, incluídas nas relações sequenciais, eixo sintagmático (Sausurre, 1983): dentro/fora (um processo interno ou externo ao indivíduo), perto/longe (a sensação de estranhamento vivenciada pelos pais em relação a seus filhos com SD), frente/trás (pensamentos que aparecem em primeiro ou segundo plano e que carregam não apenas a noção temporal de simultaneidade, mas espacial, diferenciando o 
que acontece de forma involuntária e intencionalmente) são aspectos relacionais observados cujos atributos não são de forma alguma neutros.

No eixo paradigmático ou associativo (Saussure, 1983), os significados foram identificados e analisados em contraste com aqueles ausentes que poderiam ter sido usados. A separação das narrativas em cinco grupos se deve a uma opção de organização do material de acordo com o enfoque priorizado em cada grupo. São elas: narrativas de fé, de presentes, de perda, de jornadas e de capacidades.

As narrativas de fé que compõem o primeiro grupo equivalem àquelas conhecidas como narrativas 'triunfo-sobre-tragédia', nas quais a deficiência é suplantada de forma heroica (Gray, 2009). São exemplificadas pelo livro Common Threads: celebrating life with Down syndrome, ${ }^{3}$ de Cynthia S. Kidder e Brian Skotko, publicado em 2007, composto por 68 pequenas histórias, algumas na forma de poemas, e fotografias não correspondentes aos relatos, que narram um episódio pontual na vida de pessoas com SD. Essas histórias foram coletadas, selecionadas e reescritas para compor o livro de acordo com o tema proposto no título, em que o fio comum é a fé. De modo geral, o relato parte de um fato recente, difícil de acreditar, aceitar ou mesmo de viver, que marca o ponto de corte da narrativa e, em retrospecto, conta como a pessoa viveu tal situação. São narrativas expectantes, com emoção e suspense, elementos capazes de capturar a atenção do leitor. Não são histórias de dores, e sim histórias para celebrar, uma vez que a construção dos relatos invariavelmente se traduz num quadro de sucesso, mesmo quando as condições apontam o contrário. As dificuldades são cuidadosamente descritas para dar perspectiva àquilo que precisa ser vencido; o texto parte dos obstáculos para a superação.

As imagens de caráter artístico, especialmente aquelas em preto e branco, são oníricas, angelicais, o que é sugerido pelo desfoque dos pés, pela vestimenta, pela luz: as crianças não estão 'plantadas' no chão, mas quase etéreas, flutuantes, em roupas brancas e rendas, como que em outra dimensão, outra humanidade. A convivência harmoniosa consigo mesmas, com os outros e com a natureza dá a tônica. A luz incidindo nos cabelos, na cabeça, torna-as iluminadas por uma pureza celestial, divina, 
contemplativa e pacífica, que também evoca a luz da razão, porém uma razão diferente, pura e completa, livre das amarras da imperfeição humana, o que se acentua com a presença de fenótipos pouco marcados.

O olhar frontal, encarando a câmera (ou o fotógrafo detrás dela e o leitor), exala segurança na exploração do mundo, desejo de sociabilizar, mostrando quem e como é.

As narrativas são intercaladas com resumos de pesquisas, narrados de forma a ressaltar o potencial de capacidade das pessoas com SD. Na maioria delas, é reportado que não há diferença significativa entre elas e o grupo usado como controle, tendo o pareamento sido feito de acordo com a idade mental - ou seja, as pessoas com SD são comparadas em termos de desenvolvimento com pessoas cronologicamente mais novas. Tais pesquisas testificam os eventos como extraordinários, reafirmando o ser especial e a capacidade dessas crianças em relação às outras. Segundo o livro, fé e ciência dão as mãos, uma justificando a outra. Dessa forma, propõe-se informativo ao veicular um conhecimento científico sobre o assunto, suportando pela fé aquilo que é conhecimento.

O livro é considerado um coffee table book, isto é, um livro que é para ser exibido, apreciado artística e visualmente porque, conforme dito na introdução, não é sobre a diferença, mas sobre a celebração de vidas felizes. Contraditoriamente, o texto termina com uma frase confirmando a diferença como responsável por enriquecer a vida de todos.

A figura do vencedor e o episódio da conquista tornam-se fatos. Quase todas as situações narradas envolvem algum tipo de competição ou prêmio; não basta fazer algo, é preciso ser vitorioso, materializar e tornar literais os desafios, que são colocados no lugar daquilo que precisa ser suplantado, a própria SD. Não apenas a pessoa é excepcional, exceção, diferente da regra, mas também a família. Tais conquistas contribuem para estabelecer a identidade coesa de um indivíduo autônomo.

As narrativas de presentes compõem o segundo grupo. O livro Gifts: mothers reflect on how children with Down syndrome enrich their lives, ${ }^{4}$ editado por Kathryn Lynard Soper em 2007, é um exemplo desse tipo de narrativa, no qual o elemento comum é a afirmação de que a convivência com uma 
criança que tem SD é algo para se celebrar como um presente. São 63 narrativas distribuídas em cinco presentes: respeito, perspectiva, deleite, força e amor. São relatos sobre a crise que se segue ao diagnóstico de SD para um filho; confissões sobre medos, fraquezas, preconceitos; confissões públicas para um público, perdão e reconhecimento da culpa e 'pecado' pela não aceitação ou rejeição da criança. As fotografias associadas são em preto e branco, em sua maioria retratos das crianças com SD, mas também destas e de suas mães ou mesmo da família (pais e irmãos).

Nos primeiros momentos da crise (que podem ser dias, meses), a criança pertence mais ao médico, com seus jargões, nomes de doenças ou complicações, do que aos pais, que se sentem intimidados ante o inesperado. Diante de tantos agravantes, a SD aparece como 'apenas' SD ou 'apenas' um cromossomo extra. A expectativa pelo resultado do cariótipo se traduz como a espera pela 'verdade natural' do bebê, que nesse momento soa como fado. A confirmação do diagnóstico, a princípio, impossibilita o reconhecimento daquele bebê como filho. A criança é vista ora através do olhar cromossômico, como trissomia do 21, ora através de ideias e imagens preconcebidas que tomam o espaço e impedem o contato com quem aquele bebê é, muitas vezes ofuscando qualquer outra manifestação clínica não associada à SD. Os jargões são incorporados, os nomes dos exames e das intercorrências e suas siglas passam a fazer parte do vocabulário dessas vidas.

Coragem, determinação e capacidade de luta pela vida surgem nas narrativas como inerentes a essas crianças e 'como se' conscientes, o que faz os pais se sentirem capazes também. Aqui não aparece o sema 'vencedor' ou 'campeão' no sentido materializado, mas sim figurado, pela capacidade de transpor tantas dificuldades, em sua maioria médicas.

O terceiro conjunto é formado por narrativas de perda, cujo foco é o sentimento que surge quando da morte do filho idealizado e dos sonhos a ele associados e do nascimento de um bebê com SD. O livro que ilustra esse tipo de narrativa é You Will Dream New Dreams: inspiring personal stories by parents of children with disabilities, ${ }^{5}$ de Stanley D. Klein e Kim Schive, publicado em 2001. As narrativas englobam diversos tipos de deficiência, 
entre elas a SD. Pais veteranos foram estimulados a escrever a pais novatos mensagens que gostariam de ter ouvido no momento do nascimento do filho. Validação, afirmação, suporte e encorajamento evidenciam-se nos textos. Centenas de pais enviaram suas histórias, e 63 foram selecionadas, sendo 18 sobre SD. São uma espécie de conversa, na qual o interlocutor é o público potencial. Escutar os relatos é considerado como essencial, mas como isso não é possível, as palavras escritas poderão ser de ajuda. Por serem pais há mais tempo, nota-se que as memórias já estão suavizadas, pois a descrição da crise em muitas histórias já não é mais traumática.

Entre elas, encontra-se o texto "Bem-vindo à Holanda" ("Welcome to Holland"), de 1987, escrito por Emily Perl Kingsley (Klein \& Schive, 2001), o qual se tornou amplamente conhecido, inclusive no Brasil, e que tem sido distribuído como parte do material informativo fornecido por hospitais aos pais quando do nascimento de um bebê com SD. Nele, a experiência de ter um filho com deficiência é comparada à decepção e à frustração advindas da mudança de roteiro numa viagem de férias, em que o lugar desejado (Itália) é substituído por outro (Holanda), ressaltando a importância de se vencerem tais sentimentos para então começar a se descobrirem as coisas boas do novo roteiro. Essa história é citada por muitos pais como tendo sido de grande valia no processo de aceitação do filho com a condição, e a Holanda passou a ser usada como metáfora para a SD.

Em versão ligeiramente modificada, as tulipas azuis (cuja cor em realidade se aproxima mais do violáceo, não existindo uma 'verdadeira' cor azul) da Holanda emergem como significativas e contrastam com as rosas vermelhas de Florença, na Itália, tornando-se metáforas para as conquistas (que também evocam fracassos) das pessoas com SD. Contudo, os dois países usados como roteiros, apesar das diferenças culturais estereotipadas - um mais caloroso, vibrante e desejável do que outro -, ainda assim pertencem a um mesmo contexto europeu que talvez não seja capaz de traduzir as angústias, inseguranças e dificuldades de acesso a serviços públicos existentes em países como o Brasil, e que em sentido figurado podem se aproximar do lugar horrível, desagradável e cheio de doença a 
que Emily Perl Kingsley se refere como aquele ao qual 'poderiam' mas, felizmente, 'não foram' levados.

O momento do diagnóstico dificilmente é esquecido. Numa das narrativas, a mãe ainda na sala de parto segue de perto o médico numa espécie de "dança surreal" (Klein \& Schive, 2001: 137), uma inspeção cuidadosa no corpo do bebê em busca de outros sinais que confirmem a SD. O silêncio toma conta do espaço, torna-se quase palpável, e o tempo para à espera de uma palavra ou duas sobre aquilo que ela já sabe. Sentimentos de solidão e de luto predominam, mesmo quando família e profissionais estão presentes para dar suporte, e equivalem à dor que advém da morte 'concreta' da criança. Contudo, é imperativo continuar vivendo. As atitudes diante do nascimento de um filho com SD são semelhantes às experienciadas no processo de aceitação de uma doença terminal, conforme descrito por Elizabeth Kübler-Ross (1985): negação e isolamento, raiva, barganha, depressão, aceitação. Os diferentes estágios têm duração variável, podendo ser consecutivos ou simultâneos. Não existem respostas fáceis ou prontas, mas aos poucos é possível descobrir novas formas de conviver com a situação de maneira mais proveitosa. O desapontamento e a angústia sentidos equivalem a uma ferida que só gradualmente será curada. O ponto de mudança é quando esses pais podem escutar as histórias de outros com experiências semelhantes. É possível ser feliz novamente, descobrem; sonhos morreram, o filho idealizado também. Entretanto, novos sonhos serão sonhados.

As narrativas de jornadas compõem o quarto conjunto. São livros com histórias individuais, tais como Cadê a Síndrome de Down que Estava Aqui? O gato comeu...: o programa da Lurdinha, de Elizabeth Tunes e L. Danezy Piantino (2006); Meu Rei Arthur, de Lúcia Cyreno (2007a); O Filho Eterno, de Cristovão Tezza (2007); Down (Syndrome) but not Out: a journey from grief to joy, ${ }^{6}$ de Joyce Sampson (2007); e Road Map to Holland: how I found my way through my son's first two years with Down syndrome, ${ }^{7}$ de Jennifer Graf Groneberg (2008). 
Por serem mais longas, essas narrativas contêm mais detalhes no tocante à vida dos seus autores, ainda que o fio condutor seja a presença da SD. Algumas reproduzem o processo de desenvolvimento do filho, as terapias realizadas, os programas de estimulação precoce, os momentos de aflição, tristeza, decisão, alívio. Uma delas, O Filho Eterno, de autoria do escritor catarinense Cristovão Tezza (2007) e ganhador de vários prêmios literários em 2008, destaca-se pelo nível de elaboração estética e por apresentar uma forma diferenciada de reflexão confessional, que revela uma faceta mais crua e crítica do que é ter um filho com SD. O relato trata basicamente das reflexões do personagem principal e sua 'jornada' (às vezes externa, mas muito mais interna) a partir do nascimento de seu filho no início dos anos 80, quando o tema ainda não era amplamente discutido e poucas eram as alternativas para se lidar com o fato. Ao mesmo tempo que autor e personagem se confundem, há um certo distanciamento ficcional, resultado do trabalho literário do autor, que torna o relato menos autobiográfico. $\mathrm{O}$ título, se por um lado resume um aspecto vivenciado pelas pessoas com SD, qual seja a dificuldade de abstração que permita incorporar a noção de tempo, ou a ideia de passado e futuro, tornando a experiência diária um eterno presente, por outro reafirma a imaturidade dessas pessoas e a sua necessidade de suporte.

Por fim, o quinto conjunto organiza-se como narrativas de capacidades, na forma de histórias voltadas para o público infantil, no sentido de apresentar o que é a SD e de chamar a atenção de crianças (e adultos) sobre a convivência com essas pessoas. Entre essas histórias estão os livros Where's Chimpy?, ${ }^{8}$ de Berniece Rabe (1988); a Coleção Meu Amigo Down, de Claudia Werneck (1994); Um Amigo Diferente?, também de Claudia Werneck (1996); We'll Paint the Octopus Red, ${ }^{9}$ de Stephanie Stuve-Bodeen (1998); Our Brother Has Down's Syndrome, ${ }^{10}$ de Shelley Cairo (1999); I Can, Can You?, ${ }^{11}$ de Marjorie W. Pitzer (2004); O Pequeno Rei Arthur, de Lúcia Cyreno (2007b); e Mi Amiga Tiene el Síndrome de Down,, ${ }^{12}$ de Jennifer MooreMallinos (2008). São relatos sobre a chegada do novo irmão, filho, vizinho ou colega de escola que tem SD. A preocupação presente nos livros é 
quanto à capacidade de realização da criança: o que ela pode ou não fazer e quando. Nota-se um esforço no que se refere à redefinição dos limites na SD que indiciariamente reforça um olhar de estranheza em relação a essas pessoas e seu desenvolvimento.

\section{"Ulm Blog se Alimenta DOS SEUS COMENTÁRIOS..."}

$\mathrm{Na}$ era digital, a possibilidade de compartilhar e de se comunicar instantaneamente transforma as práticas culturais de preservação de memórias e de trocas de experiências. Novas tecnologias contribuem para o surgimento de novas formas de construção e modelagem do self, como, por exemplo, os blogs.

Blogs têm múltiplos antecedentes. Um deles é o termo log utilizado na linguagem naval, que consiste num dado cronológico atualizado periodicamente e necessário à navegação. Assim, sua utilização torna-se condizente com as imagens metafóricas aplicadas à Internet, sugerindo dados de uma jornada que pode ser significativa para outras pessoas (Miller \& Shepherd, 2004).

Os diários em papel, formas culturais entendidas como privadas, mas que sempre contiveram um aspecto de compartilhar, ainda que com uma audiência restrita, foram em certa medida substituídos pelos lifelogs, seu correspondente digital, embora não coincidentes em sua totalidade. Os lifelogs visam ao compartilhamento de experiências e subjetividades, mais do que à expressão individual ou à reflexão, como poderia ser entendida a função dos antigos diários (Van Dijck, 2007). Neles, o proprietário (ou autor) faz - ou posta, numa analogia com o correio - atualizações regulares, que podem seguir um tema específico, eventos ou pensamentos e reflexões. Existe ainda espaço para comentários dos leitores diretamente no blog ou por e-mail, permitindo o contato com o autor e com outros leitores, além de links para diferentes websites (Blanchard, 2004).

No âmbito do fenômeno dos blogs, a interseção entre as dimensões pública e privada é redesenhada: ao mesmo tempo que o blog é um espaço 
confessional cujo caráter do conteúdo é basicamente pessoal, busca ser reconhecido como parte de uma comunidade (Badger, 2004; Van Dijck, 2009). O público ao qual se dirige pode ser qualquer um, mesmo no caso daqueles voltados à discussão e à divulgação de experiências de famílias em que está presente uma condição genética como a SD. A sua ampla expansão parece relacionar-se não apenas às crescentes facilidade de acesso à rede e disponibilidade de tecnologias digitais de fácil manuseio e mais baixo custo, mas também à necessidade de se comunicar algo que de outra forma não seria possível.

A noção de blog torna menos delimitada a fronteira entre autor e leitor, na medida em que permite um canal de manifestação de dupla via, criando uma sensação de envolvimento, além de possibilitar ao leitor uma reordenação da narrativa de numerosas formas (Himmer, 2004). Diferentemente dos livros, nos blogs a ênfase recai sobre o processo mais do que sobre uma posição definida e fechada; a instabilidade é maior, e as mudanças de perspectiva ou mesmo de opinião podem emergir mais facilmente.

Nos blogs analisados, o intervalo entre uma entrada (post) e outra varia de acordo com os autores ou com o momento de vida de cada um; os assuntos abordados, em geral, tratam de temas ligados ao processo de desenvolvimento da criança com SD - as dificuldades clínicas, os preconceitos e, principalmente, as conquistas diárias, seja na escola, seja nas várias atividades de estimulação a que é submetida rotineiramente. As fotografias associadas são instantâneos capturados pela lente amorosa de pais e familiares e servem mais como registros a serem compartilhados do que como preservação de memória.

Predominantemente, os blogs são criados a partir do fato de se ter um filho com SD e são escritos por mães em primeira pessoa, e alguns pais, mas também 'como se' dando voz ao(à) filho(a) com SD. Narram episódios familiares, mas, sobretudo, texto e imagem são dispostos com o propósito de dar a conhecer quem são os membros dessa família, como é e como vive alguém que tem SD.

Ainda que muitos utilizem pseudônimos, transparece uma forma de se manter compromisso com a 'verdade', reforçado pela exibição livre 
das fotografias; de confessar as fraquezas, as rejeições e os medos; de não esconder o sentido e o executado, pois cada uma dessas ações ou emoções pode ser de ajuda para outros pais. ${ }^{13}$

Cada blog traz referências a outros blogs escolhidos como parte de um grupo que compartilha aspectos comuns, num desdobramento que tende à circularidade, manifesta no entrecruzamento das referências e do material informativo, como livros, entrevistas e reportagens.

Nos blogs, as relações sequenciais no eixo sintagmático evidenciam-se primordialmente na cronologia, ainda que inversa, das entradas (as novas entradas e a respectiva hora de postagem são incorporadas no topo da página) e criam a noção de continuidade da narrativa, gerando expectativas e envolvendo o leitor em acontecimentos de vidas que não a sua, mas que de certa forma refletem aspectos comuns, tornando-os significativos. São observadas também na ordem escolhida para dispor as imagens, podendo compor uma narrativa em separado. A inversão cronológica sugere ainda uma proximidade com a experiência presente do autor, que reforça a ideia do relato como não ficcional.

As relações sintagmáticas espaciais incluem aspectos como acima/ abaixo, esquerda/direita, figura/fundo, salientando ora texto, ora imagem. A presença e a distribuição dos elementos visuais - a divisão da tela em colunas, o uso de imagem e cor, a escolha de caracteres e fontes possibilitam uma leitura não verbal do material frequentemente mais abundante em significados do que a parte verbal (Miller \& Shepherd, 2004).

Apesar da grande variedade de formas e cores que servem à individualização, de modo geral os elementos constituintes dos blogs são: textos que seguem o formato de diário e podem se localizar tanto à direita quanto à esquerda na tela; espaço para comentários (por exemplo, um ícone de um polvo com extensões semelhantes a raízes e galhos, ou de um dinossauro, com a mensagem-convite de que "un blog se alimenta de tus comentários"), reforçando a ideia de conectividade e interatividade; fotos de vários eventos (férias, aniversários, nas várias terapias, na escola, em casa...); vídeos; calendário; hora (relógio nos mais variados formatos); contagem dos aniversários; contador de visitas; dados pessoais da criança e 
dos pais; arquivo com as entradas mais antigas; desenhos (inclusive na forma de 'papel de parede'); quadros com propaganda; links para outros blogs, para notícias publicadas em outros meios de comunicação e para sites institucionais de interesse; fotos de crianças com alguma deficiência que estão à espera de adoção; prêmios dados ao blog por outros leitores (bloggers). A forma como o autor dispõe esses elementos e a prioridade que é dada a cada um variam de acordo com o gosto e o estilo pessoais e com aquilo que é escolhido para ser compartilhado e comunicado.

Carlos Novas (Novas \& Rose, 2000), em seu trabalho com webforums sobre doença de Huntington, identificou quatro dimensões nas tecnologias do self. A primeira delas diz respeito a uma identidade genético-molecular, construída basicamente com elementos médicos relativos à presença $e$ à transmissão de uma condição específica. Envolve discussões quanto a se submeter ou não a testes preditivos e as possíveis consequências, sendo uma delas o experienciar da condição de indivíduo sob risco genético, que passa a se pensar como um ser genético-molecular.

A segunda dimensão refere-se a um domínio ético que indivíduos assintomáticos ou sob risco têm que confrontar e que abarca decisões tais como ter ou não filhos, ou ainda como e quando revelar a filhos e familiares a possibilidade de terem herdado uma condição genética e de fazer determinados testes preditivos.

A terceira dimensão é concernente ao fato de que tais indivíduos, em decorrência do conhecimento adquirido por meio da vivência e de numerosas fontes, não apenas médicas, e da solicitação (externa e interna) por responsabilidade e autonomia, tornam-se experts leigos, configurando novas formas de relação com o conhecimento especializado e buscando caminhos para a otimização de saúde e bem-estar.

Por fim, a quarta dimensão abarca o que Novas nomeou estratégias de vida, maneiras de se lidar com a vida no presente (Novas \& Rose, 2000), mas tendo em mente um eixo temporal que a liga ao futuro, um futuro marcado por risco em termos genéticos, por meio de objetivos, tarefas ou estágios. 
Nas narrativas sobre SD, é possível observar essas quatro dimensões, ainda que com certas diferenças. A identidade que se configura em indivíduos com SD é calcada em aspectos médico-genéticos, mas em razão de uma situação que já é dada. Ou seja, são os pais, parentes, pessoas próximas que começam a construí-la por ocasião do diagnóstico intraútero ou do nascimento da criança, sendo paulatinamente assimilada pelas pessoas que têm SD. Com exceção dos casos em que existe uma translocação que foi herdada, a grande maioria deve-se a uma irregularidade na divisão celular que aconteceu ao acaso e que é considerada como um 'acidente genético'. Nesses casos, não existem 'indivíduos suscetíveis a desenvolver $\mathrm{SD}^{\prime}$, no mesmo sentido que em outras configurações genéticas, mas pais e mães com determinado nível de risco de terem um filho com essa condição, especialmente em se tratando de mulheres com mais de 35 anos. ${ }^{14}$

A presença da SD numa criança representa uma quebra na vida daqueles que com ela convivem e introduz as dificuldades e preocupações a serem enfrentadas referentes à possibilidade de um futuro autônomo $e$ produtivo (às vezes também reprodutivo) de seu filho, requerendo uma reestruturação do tempo em termos de foco e disponibilidade e uma reavaliação dos planos e prioridades (Morgan \& Thomas, 2009). A vivência do presente torna-se um elemento fundamental no sentido de que não há como imaginar o futuro de alguém com $\mathrm{SD}$, pois as expectativas e os ideais foram lançados por terra com a ruptura do padrão de normalidade aceito socialmente, e também pela dificuldade dessas pessoas em realizar a abstração que carreia a noção de tempo e que dá dimensão ao que é passado e ao que é futuro, alterando a percepção de todos à sua volta.

Pouco a pouco, o que era inexperiência e ignorância no assunto, parcial ou completa, transforma-se em conhecimento, não apenas pela aquisição de novas informações médicas, mas pela vivência, capacitando pais e parentes de pessoas com SD como novas formas de autoridade que podem se aliar a autoridades especializadas já estabelecidas ou confrontá-las.

A vida com a SD também se pauta por metas a serem alcançadas numa linha temporal. Novas estratégias de vida substituem as antigas, assim como novas expectativas substituem as que foram frustradas. 
Definitivamente, a vida foi alterada à luz da $\mathrm{SD}$, e o presente deve ser administrado para que o futuro dessas pessoas possa ser o melhor possível diante de algo que é irreversível.

\section{Significados, o Desenho do Rendilhado}

O discurso nas narrativas veiculadas em livros e blogs mostra-se ambivalente: por um lado, existe a marca daquilo que é inesperado e resulta em diferença no que concerne ao desenvolvimento da criança, às expectativas, ao estigma social, e que se expressa como valorização da multiplicidade inerente a essa diferença. Tal atitude pode ser resumida pela frase "eu sou especial", ${ }^{15}$ um consenso nas histórias. Por outro lado, o discurso é focado na aceitação da diferença por meio da sua normalização, sendo povoado por imagens que traduzem essa ambivalência e ressignificam aquilo que é característico da SD, num tom de exaltação crescente, com profusão de adjetivos, como nas frases "uma cópia extra do cromossomo 21, bênçãos extras de Deus", ${ }^{16}$ "um cromossomo extra, que torna as pessoas extra-adoráveis", ${ }^{17}$ "fofura vem com um cromossomo extra" ${ }^{18}$ Um tom de competição é assumido em muitas narrativas, nas quais a presença do cromossomo extra revela-se como aprimoramento das características vitais da pessoa, valorizando-a: "meu filho tem mais cromossomos do que o seu"; 19 "síndrome de Down ou trissomia do 21 ou T21... até melhor, com um gene de grife!"; 20 "eu sou aprimorada geneticamente!"21

Conjuntos de semas compostos por diversos níveis de significados se repetem uma e outra vez ao longo das narrativas. Eles condensam atitudes e sentidos por meio dos quais as pessoas descrevem suas próprias experiências e as tornam significativas. A presença deles permitiu a própria organização do material pesquisado, desdobrando-os em suas sutilezas e ensejando o desvelar de eixos temáticos comuns. 'Diferente', 'especial', 'anjo', 'príncipe e princesa', 'capacidade' e 'vencedor' são alguns deles, verbalizados na tentativa de se traduzir em atributos a identidade difusa de alguém que traz a marca da alteração genética como elemento principal. Em alguns relatos, tais significados aparecem para serem contraditos, numa tentativa de se romper com estereótipos usados para rotular essas 
pessoas. Porém, nem sempre essa ruptura é lograda, tal é a força desses atributos no ideário sobre o tema.

Genes são vistos popularmente como fenômenos naturais isentos de significados resultantes de interações sociais, isto é, entidades da natureza objetivamente descritas e preexistentes. Entretanto, genes e corpos, assim como outros elementos naturais-tecnológicos, emergem de um processo discursivo (Haraway, 1992).

O mesmo tende a ocorrer com a SD: além do padrão de normalidade, as narrativas sugerem a perspectiva do natural como a mais adequada para compreender a síndrome e as pessoas que a apresentam, desconsiderando que a SD existe não apenas como condição orgânica, biológica, mas também como construção discursiva, resultado da interação entre diversos atores, humanos e não humanos (Haraway, 1992). O natural, aqui, ocupa o lugar daquilo que é inerente à pessoa, e que responde pelo mais básico do seu ser, sua corporalidade e os atributos identitários recebidos como herança, como a cor dos olhos, dos cabelos ou o temperamento, mas é uma herança que, em realidade (salvo nos casos de translocação), resulta de uma abrupta desregulagem, como no texto de João Gilberto Noll (2003). O natural também diz respeito a uma espécie de força determinante ou causa biológica, que define a SD. A pessoa e a condição genética se confundem: a divisão celular diferente da normal e que leva à não disjunção do cromossomo 21 é metonimicamente colocada no lugar da criança que tem SD, desencadeando uma forte reação em defesa da 'adequação' do filho. O cromossomo 21 extra torna-se sinônimo da condição SD e adquire existência e identidade independentes da criança, sendo referido como um dos membros da família.

A ótica do natural tem a intenção de destituir a pessoa que nasce com SD de seu caráter de desviante, ilusoriamente eliminando as acepções negativas ou discriminatórias a ela associadas. Subjacente a essa perspectiva, e aqui retoma-se a proposta de Ian Hacking (2000), encontra-se o entendimento da SD como um 'tipo' indiferente, e por isso incapaz de alterar o seu objeto de classificação, uma condição de base genética, determinada pelo excesso de carga gênica de um terceiro cromossomo no par 
21. Porém, apesar da sua base genética, o termo também se refere a um 'tipo' interativo, uma vez que a classificação interage com as pessoas que com ela nascem, alterando o modo como elas se percebem, agem e se ajustam a tal classificação.

Então, o que é considerado como sendo perspectiva do natural na verdade acresce mais um elemento na composição da ideia sobre as pessoas com SD. Elas tornam-se ícones no sentido de reprodução da natureza cultuada como sagrada; pessoas não corrompidas pela mediocridade humana, vivendo em harmonia com os preceitos da natureza. A conexão com a natureza dissimula a diferença e devolve à pessoa a imagem do 'mesmo', ainda que deslocado ou distorcido, como nos fenômenos ópticos de reflexão e refração (Haraway, 1992). Fornece, ainda, uma resposta que amaina as angústias decorrentes da falta de controle no que se refere ao risco e à prevenção, especialmente na trissomia livre, grande maioria dos casos.

A 'jornada' está presente em todas as narrativas, ora num sentido claramente metafórico, ora num discurso naturalizado que sinaliza o seu esvaziamento e a sua instauração como mito. É um tema identificado também em pesquisa realizada por Rayna Rapp (2000) com grupos de apoio para pais de crianças com SD.

O tema da jornada ou peregrinação é encontrado em vários sistemas mitológicos de diferentes culturas em dois aspectos: o primeiro deles é a jornada empreendida pelo herói em direção ao desconhecido para o cumprimento de tarefas necessárias ao fortalecimento de sua personalidade. No percurso, ele descobre seus próprios recursos ou tem acesso a poderes superiores que o ajudam. O retorno do herói revigorado pelo conhecimento adquirido (inclusive sobre si mesmo) é uma etapa fundamental e que completa o ciclo. O segundo aspecto é a jornada com caráter de libertação, de renúncia e expiação, com um fim último de transcendência, com a orientação de um guia espiritual (Henderson, 1996).

Nas narrativas, a jornada evoca a perda de rumo, mas diferentemente da jornada do herói, não há volta possível. O rumo foi perdido para sempre, e outro caminho tem de ser encontrado. É uma aventura em direção ao desconhecido, a algo que é inatingível, dando dimensão aos percalços e 
desafios enfrentados, e que pode ser comparada à metáfora da jornada espacial tão usada na genética, na qual a conquista do espaço infinito é possível graças aos avanços da tecnologia humana.

São os pais que, obrigados a deixar a segurança do conhecido, partem nessa aventura em busca do fortalecimento de si mesmos. E nesse percurso reconhecem na figura do próprio filho com SD o papel do guia ou professor iluminado, especial, diferente, aquele que sabe o verdadeiro caminho, persistente, determinado, genuíno, não corruptível, em harmonia consigo e com a natureza, capaz de ensinar a todos na família e no mundo, por ser um presente de Deus, uma espécie de mediador espiritual. Cada sinal revelador da SD ganha uma dimensão metafórica que transforma o olhar sobre essas pessoas, como as manchas de Brushfield, por exemplo, aquelas pequenas nódoas brancas e brilhantes visíveis nos olhos de indivíduos com SD, que se tornam "estrelas" (Klein \& Schive, 2001: 22).

Esse é o modo como as famílias conseguem lidar com o vértice do impensável, com o choque, o desespero, o medo diante do desconhecido e do 'defeituoso' ou 'partido'. ${ }^{22}$ As tarefas fazem parte da jornada, relacionadas à sobrevivência deles, pais, diante da morte do filho desejado e esperado, como forma de dar sentido ao vazio interno. A possibilidade de interromper a gestação está sempre presente, de forma mais ou menos clara, oferecida pelos médicos (em países onde isso é possível) ou pensada pelos pais. A ideia de que é filho deles e que é natural a sua vinda, e consequentemente a sua aceitação (não se pode esquecer que a SD já está presente de forma inexorável), surge como justificativa para não fazê-lo. Os olhos amendoados são a chave, a descoberta de algo diferente - "por favor, feche os olhos", diz a mãe na sala de parto (Klein \& Schive, 2001: 137) - e também a explícita doçura em cada um deles, afinal, não são os olhos o espelho da alma? Ou, como diz Fernando Pessoa (2008), do movimento da alma?

O sistema mitológico que serve de base para a compreensão da presença da SD é o judaico-cristão, com suas narrativas de salvação e seu Cristo que vem para libertar os humanos do pecado e ensinar aquilo que foi perdido no viver mesquinho; o deus triste e comovido que consola os 
que sofrem, a que Ricardo Reis, heterônimo de Fernando Pessoa (1994), alude como aquele que faltava no panteão dos antigos deuses. Em termos junguianos (Jung, 2000), a pessoa com SD sugere uma manifestação do arquétipo $^{23}$ da criança divina, evidenciado no paradoxo inerente ao herói de ser a um só tempo frágil e indefesa, mas também possuidora de forças que ultrapassam a medida humana e adentram o domínio do divino. A família sente-se tocada pela SD como por um milagre, abençoada pela presença de um cromossomo a mais, o que de certa forma dilui a responsabilidade por uma decisão quanto a manter a gestação. O significado de mediador ou guia espiritual em harmonia consigo mesmo e com a natureza, atribuído às pessoas com $\mathrm{SD}$, faz parte dessa mitologia e remete o leitor à Cidade de Deus de Santo Agostinho.

Civitate Dei foi escrito por Santo Agostinho entre os anos 413 e 427 (Saint Augustine, 2003). Considerado um clássico, o livro ainda hoje é constantemente reeditado pela sua importância histórica e por ser uma fonte do ideário cristão. Nele, o autor escreve sobre uma cidade cujos laços entre as pessoas são de amor, estando unidas por um senso comum de bondade e justiça. Constantemente citada, outra cidade é contraposta à cidade celeste: a cidade terrena. Ambas estão entrelaçadas em sua existência, e os seres humanos e angélicos que as habitam não teriam consciência de a qual delas pertenceriam. Sem a queda dos anjos e de Adão e Eva, as duas cidades não teriam razão de ser.

As raízes maniqueístas de Santo Agostinho estão aqui presentes quando ele descreve seus habitantes em dois grupos: aqueles que optaram por viver de acordo com os princípios da carne e os que optaram pelos princípios do espírito. Entretanto, ele afirma, o pecado se apresenta na alma e não no corpo; suas evidências carnais são apenas consequência de sua instalação na alma. Deus a tudo criou em perfeita harmonia em sua natureza, e uma grande importância é dada por Santo Agostinho ao fato de os homens serem criaturas racionais, cuja característica principal é o livre-arbítrio. Seria pelo livre-arbítrio que cada homem escolheria ser habitante da cidade terrena ou da Cidade de Deus. 
Os significados explicitados nas narrativas ecoam o texto de Santo Agostinho. A presença do retardo mental impele ao movimento de substituição da inteligência e de sua medida, a razão, como bens supremos de uma pessoa, por qualidades que os homens parecem ter esquecido. Assim, as pessoas que têm SD são apresentadas como em estado de pureza, libertas das limitações que poderiam levá-las a fazer escolhas em desacordo com os princípios do espírito e da luz. O corpo 'imperfeito' não as impede de viver os laços de amor prevalentes entre os habitantes da Cidade de Deus. Seres humanos ou angélicos, considerando-se a metáfora do 'anjo' prevalente nos textos, as pessoas com SD são elevadas ao que o homem comum não é: a capacidade de amor incondicional, a vivência do presente, o ritmo de vida mais lento de acordo com as possibilidades de cada um são características que o homem contemporâneo parece ter perdido e não consegue reencontrar. Com a presença dessa criança, isso seria novamente possível. Todo lar deveria ter uma criança com SD; sua existência faz diferença no mundo, é dito (Soper, 2007).

A 'imperfeição' genética na forma de SD apresenta-se como algo a ser prezado como um raro tesouro, como na analogia com as lagostas azuis (que lembram as tulipas azuis, ${ }^{24}$ já mencionadas), descrita num dos blogs. ${ }^{25}$ Resultado de uma anomalia genética, as lagostas azuis, cuja ocorrência é de uma em dois milhões, são celebradas pelos pescadores e consideradas especiais justamente por sua constituição 'imperfeita', diferente do padrão.

De forma complementar à análise dos livros e blogs, observou-se que esses mesmos significados estão presentes em algumas produções cinematográficas que trazem personagens com SD. O filme norte-americano A Sétima Profecia (The Seventh Sign), de 1988, dirigido por Carl Schultz, explicita a associação entre a SD e a mitologia judaico-cristã. Classificado como drama, mas com pinceladas de suspense, o enredo aborda o evento do Apocalipse, conforme descrito no Livro das Revelações. Um a um, os sinais que antecedem o fim do mundo se manifestam, e uma mulher, prestes a dar à luz, vê-se envolvida na terrível cadeia de eventos. Um desses sinais é a morte do mártir, representado por um rapaz com SD que 
assassinou os pais, irmãos entre si, para puni-los por incesto, seguindo os preceitos de Deus (seria a SD já um castigo divino?). Assassino por livrearbítrio destinado à pena de morte, ser humano considerado incapaz e não responsável por seus atos por ter $\mathrm{SD}$, ou ser humano puro que age de acordo com a lei de Deus são as perguntas lançadas pelo filme.

O sentido da criança com SD como reparação na vida de pais e familiares é marcante, reparação por uma vida vazia, egoísta, autocentrada. A quebra na continuidade entre o passado e o presente é transmutada em justificativa para a sua vinda. Por meio dessas crianças, os habitantes da cidade terrena podem se aproximar da cidade celeste, a Cidade de Deus. Após a perda da perfeição inicial idealizada para o filho, outra perfeição é alcançada, descrita como mais pura, mais desejada, mais 'perfeita'. As conquistas são alcançadas mais tarde, mas quando ocorrem são perfeitas. Perfeição é, então, definida nas narrativas como aquilo que esses filhos são capazes de trazer aos outros e que os eleva como humanos. Esse sentido é retratado no filme inglês AfterLife, ${ }^{26}$ de 2005, dirigido por Alison Peebles, no qual um jovem e ambicioso jornalista, que prepara uma reportagem sobre um médico suspeito de assistir o suicídio de pacientes terminais, ao saber que sua mãe está com câncer em fase terminal, vê-se obrigado a cuidar de sua irmã que tem SD. A situação de doença da mãe e a convivência com a irmã leva-o a reavaliar sua vida, suas responsabilidades e sua incapacidade em se aprofundar nas relações interpessoais.

Seguindo outra linha de abordagem, o episódio 22 da terceira temporada do seriado Lei e Ordem: unidade de vítimas especiais, "Competência" (Law \& Order: special victims unit, "Competence"), de 2002, produzido pela rede NBC, de certa forma apresenta outra faceta dessas asserções. Nele, uma adolescente com SD aparece grávida, e a alegação de abuso sexual, baseada na falta de informações da adolescente sobre sexo, conflita com o seu desejo de ter o bebê, pois a incompetência no primeiro caso significaria também uma incompetência no segundo. O filme traz às telas a discussão sobre a capacidade das pessoas com SD de fazer escolhas autônomas sobre suas vidas - no caso, ser capaz de recusar um assédio sexual e criar um filho. 
Mais recentemente, o personagem principal do filme de Pedro Almodóvar Abraços Partidos (Los Abrazos Rotos), de 2009, um escritor que ficou cego após um acidente, quer escrever uma narrativa de superação e diz-se inspirado pela história do escritor e diretor Arthur Miller, o qual teve um filho com SD na década de 1960 e o colocou numa instituição ainda recém-nascido, aparentemente eliminando-o de sua vida pública e privada. Segundo publicado no jornal inglês Telegraph, versão on-line, em 18 de abril de 2009, Almodóvar desenvolveu o argumento do filme com base nesse fato, com a intenção de discutir os efeitos perversos nas relações entre pais e filhos. No filme, a alusão feita ao reencontro público entre pai e filho exalta a falta de rancor ou a presença de uma bondade inata que permitiu ao filho abraçá-lo afetuosamente apesar da rejeição.

Em certo sentido, a presença do retardo mental na SD e, de modo geral, de deficiências em outras condições revela uma forma de infantilização que, segundo Rapp (2000), remonta a uma vertente evolucionária característica do pensamento intelectual ocidental do século XIX e que faz referência a determinados grupos culturais como representantes de uma etapa anterior do desenvolvimento humano. De forma equivalente, pessoas que apresentam alguma deficiência são homogeneamente 'infantilizadas', sendo vistas como social e psicologicamente dependentes, incapazes de compatibilizar os conflitos relacionados ao crescimento e amadurecimento.

Pais de pessoas com SD tornam-se militantes no sentido de tentar mudar tal concepção no viver diário, mas frequentemente são capturados nos meandros desse pensamento, lançando mão de discursos ambivalentes para acomodar ambas as perspectivas. Ainda que reconheçam as conquistas alcançadas, surpreendem-se assombrados por fantasmas do futuro que turvam a claridade do presente. 
1 Em tradução livre: "a vida não é a que se viveu, mas a que se recorda e como se recorda para contá-la".

2 As ultrassonografias tri e quadridimensionais são usadas não apenas para investigar suspeitas relativas ao desenvolvimento fetal, mas também para fins não diagnósticos, como a produção de 'fotografias' e a possibilidade de se estreitar o vínculo com o bebê, por exemplo. Em países como o Reino Unido, essas técnicas estão ligadas aos debates sobre aborto, em especial sobre o tempo limite para a sua realização (Palmer, 2009).

3 Sem título em português. Em tradução livre: Fios Comuns: celebrando a vida com síndrome de Down.

4 Sem título em português. Em tradução livre: Presentes: mães refletem sobre como crianças com síndrome de Down enriquecem suas vidas.

5 Sem título em português. Em tradução livre: Você Sonhará Novos Sonhos: histórias pessoais inspiradoras de autoria de pais de crianças com deficiências.

6 Sem título em português. A primeira parte do título faz um jogo de palavras com a expressão down-and-out, que significa fracassado, destituído, deixando claro, portanto, que ter SD não significa ser fracassado. A segunda parte complementa: uma jornada do luto ao contentamento.

7 Sem título em português. Em tradução livre: Mapa de Percurso para a Holanda: como encontrei meu caminho durante os dois primeiros anos do meu filho com síndrome de Down.

8 Sem título em português. Em tradução livre: Onde Está Chimpy? (um macaco de pelúcia).

9 Sem título em português. Em tradução livre: Nós Pintaremos o Polvo de Vermelho.

10 Sem título em português. Em tradução livre: Nosso Irmão tem Síndrome de Down.

11 Sem título em português. Em tradução livre: Eu Posso, Você Pode?

12 Sem título em português. Em tradução livre: Minha Amiga Tem Síndrome de Down.

13 Essa atitude também está presente no blog de uma mãe que entregou o filho com SD para adoção e que se considera ligada à comunidade $\mathrm{SD}$, apesar de achar que não tem esse direito. Disponível em: <http://havefallendown.blogspot.com>.

14 Aproximadamente 1/1.400 entre 20-24 anos e 1/100 aos 40 anos (Nussbaum, McInnes \& Willard, 2002).

15 Frase extraída do blog Where There's a Will. O nome do blog faz um jogo de palavras entre o nome da criança (Will) e o conhecido refrão "where there's a will, there's a way", cujo significado alude à capacidade de determinação que faz encontrar um caminho. Disponível em: <http://willswebplace.blogspot.com>. 
16 Frase extraída do blog Extras. Disponível em: <http://gotsnow.org > . No original: An Extra Copy of the 21st Chromosome; Extra Blessings from God.

17 Frase extraída do blog <http://hiddentreasuresthet21journey.blogspot.com > . No original: An Extra Chromosome that Makes People Extra Lovable!

18 Frase extraída do blog <http://megansgot47.blogspot.com>. No original: Cuteness Comes with an Extra Chromosome.

19 Frase extraída do blog <http://churchillchronicle.blogspot.com>. No original: My Kid Has More Chromosomes than Yours.

20 Frase extraída do blog <http://hapagirlhapafamily.blogspot.com>. No original: ...DOWN SYNDROME or Trisomy 21 or T21... Even Better, with a Designer Gene!

21 Frase extraída do blog < http://zoromski.blogspot.com>. No original: I'm Genetically Enhanced!

22 Em muitas narrativas, as crianças com SD ou alguma outra deficiência são referidas em discurso como crianças partidas. No original: Broken Children.

23 Arquétipo, segundo Carl Gustav Jung (2000: 17), "representa essencialmente um conteúdo inconsciente, o qual se modifica através de sua conscientização e percepção, assumindo matizes que variam de acordo com a consciência individual na qual se manifesta".

24 Não se pode esquecer que na língua inglesa a cor azul está associada a sentimentos de tristeza e melancolia, os quais também estão presentes nas narrativas, relacionados à morte de um ideal de filho(a).

25 Disponível em: <http://mybluelobster.blogspot.com>.

26 Sem título em português. Em tradução livre: Após a Vida. 